\title{
Breastfeeding is Best. But What After Breastfeeding?
}

Received 19 November 2018

Yvan Vandenplas ${ }^{1}$, Badriul Hegar ${ }^{2}$, Ray Wagiu Basrowi ${ }^{3}$

Accepted 10 December 2018

KidZ Health Castle, UZ Brussel, Vrije Universiteit Brussel, Belgium

2. Department of Child Health, Faculty of Medicine, Universitas Indonesia

Link to DOI:

10.25220/WNJ.V02.i2.0001

Journal Website:
www.worldnutrijournal.org

Long-term exclusive breastfeeding is definitively the best feeding for every infant. Exclusive breast feeding should be for six months. From the age of six months onwards, solid food should be introduced while breast feeding is continued. ${ }^{1}$

There are only very few contra-indications for breast feeding or mother's milk. A maternal severe disease is an example of a contra-indication for breast feeding. If a mother has to take medication or undergo a treatment that may have a deleterious effect on the health of the baby, such as chemotherapy or radiotherapy, breast feeding cannot be recommended. ${ }^{2}$

In such a situation, mother's milk from a different mother or a "milk bank" may offer a solution. If this are not possible, infant formula is indicated. Some seldom metabolic diseases such as galactosemia are also contra-indications for mother's milk, because in such a situation lactose is causing severe damage to the baby. Cow's milk based lactose containing infant formula is then as well contra-indicated, since the baby cannot metabolize lactose. However, it speaks for itself that these situation are exceptional. 3,4

\footnotetext{
Corresponding author:

Yvan Vandenplas, $P D, P h D$

KidZ Health Castle

UZ Brussel, Vrije Universiteit Brussel, Brussels,

Belgium

Tel: 003224775794. Fax:003224775783.

Email:Yvan.Vandenplas@uzbrussel.be
}

Chronic malnutrition and failure to thrive is still an important issue in Indonesia, since recent figures from RISKESDAS 2018 report that around $30.8 \%$ of infants and young children up to 5 years old are stunting. Other data showed that the prevalence of stunting in 0.5-1.9 years old in the Indonesian rural and urban areas was $24.3 \%$ and $28.9 \%$, respectively. ${ }^{5,6}$

However, introduction of solid food from 6 months onwards, and certainly before the age of 12 months, is recommended by all guidelines. These epidemiological data suggest that diversification of feeding in an infant after the period of exclusive breastfeeding is a problem, and that the nutritional quality of the solid food introduced is insufficient to cover the caloric and nutrient needs of the infants. ${ }^{6}$ Looking at these observations from outside, an analysis of the deficiencies and development of adapted guidelines on "how to introduce complementary feeding" seems to a priority topic for research.

The older an infant becomes, the smaller the volume and nutritional impact of mother's milk. However, mother's milk is rich in bioactive proteins and oligosaccharides, which are components improving the protection of the child against infectious disease. The content of these protective components in mother's milk decrease over time: the longer the lactation, the smaller the amount of these protective factors. ${ }^{7}$ Since infectious disease and as a consequence death and morbidity such as 
failure to thrive and stunting growth are a major health issue in toddlers, the question arises is ageadapted cow milk best formula fortified with some of these protective factor should be recommended or not. Of course, evidence should be obtained before recommendations can be made. Prospective, double blind, randomized trials with normal cow milk in eg 1-3 year old children versus age-adapted special formula should give the answer to this question. The benefit of the addition of probiotics, prebiotic oligosaccharides and other components such as secretory IgA to toddler's formula should be studied. These studies should not only focus on health outcome, but also on the cost/benefit ration.

Specialized formula or solid food will obviously be more expensive than regular cow milk or consumption of unbalanced solid food. However, this extra cost on the short term may result in an economic benefit on the middle or long term. Because if the nutritional status of the toddlers improve, the incidence of failure to thrive will drop down and infectious disease will decrease. And as consequence, health care cost will decrease. Thus, spending some extra money on the short term may safe larger amounts of money later. If this benefit has been clearly demonstrated, government might find it beneficial to support the consumption of ageadapted fortified foods in 1-3 years old toddlers.

\section{Conflict of Interest}

Authors declared no conflict of interest regarding this study.

\section{Open Access}

This article is distributed under the terms of the Creative Commons Attribution 4.0 International Licence (http://creativecommons.org/licenses/by/4.0/), which permits unrestricted use, distribution, and reproduction in any medium, provided you give appropriate credit to the original author(s) and the source, provide a link to the Creative Commons license, and indicate if changes were made.

\section{Reference}

1. World Health Organization. Exclusive breastfeeding. E-Library of Evidence for Nutrition Actions (eLENA). Downloaded from:

http://www.who.int/elena/titles/exclusive b reastfeeding/en/ [diakses pada 9 Jan 2016]

2. Health Canada; Canadian Paediatric Society; Dietitians of Canada; Breastfeeding Committee for Canada (2012) Nutrition for healthy term infants: recommendations from birth to six months. Can J Diet Pract Res 73:204

3. Martin CR, Ling PR, Blackburn GL (2016) Review of infant feeding: key features of breast milk and infant formula. Nutrients 8:279

4. Kerner JJ. Formula allergy and intolerance. Gastroenterology Clinics of North America 1995;24(1):1-25. [Google Scholar]

5. Badan Penelitian. Riset kesehatan dasar. Jakarta: Kementerian Kesehatan RI (2018)

6. Sandjaja S, Budiman B, Harahap H, Ernawati F, Soekatri M, Widodo Y, et al. Food consumption and nutritional and biochemical status of 0 - 5-12-year-old Indonesian children: the SEANUTS study. British Journal of Nutrition 2013;110(S3). [Google Scholar]

7. Nutrition, C.o. (ESPGHAN) . Breastfeeding: A Commentary by the ESPGHAN Committee on Nutrition. J Pediatr Gastroenterol Nutr 2009;49(1):112-25. [Google Scholar] 